\title{
Support Your Own, on Your Own: Local Government Subsidies for Jewish Institutions during the Period of Galician Autonomy, 1866-1914 ${ }^{1}$
}

\author{
Hanna Kozińska-Witt \\ (Jagiellonian University, Kraków) \\ e-mail:kozinska@web.de
}

Key words: Galicia, Krakow, Lwów, Jewish poor, municipal self-government, poor law, Jewish welfare, charity, subsidies

Abstract: This article presents and analyses legal acts that influenced the situation of Jews in Galicia and shaped the local co-existence of Jewish communities and municipalities. It concentrates on subsidies provided to Jewish charities and welfare institutions by municipal funds. The subsidizing policy of Krakow is compared with that of Lwów.

During research for my previous project, I encountered a whole host of Jewish institutions, which the city of Krakow subsidised in the interwar period. These included the Hisaharu Bibne Amin Society for Supporting Jewish Boys, a school for the illiterate, a school of servant women, the Chawre Machzike Naare Bute Sefer Society for Providing Poor Jewish Schoolgirls with Clothing and Footwear, the Krakow group of the Hope Association for Supporting Poor Young Girls of Higher and Middle Schools, and the Jewish hospital. ${ }^{2}$ Local government subsidies of Jewish institutions seem to have followed certain clear rules, although these were not clarified in the interwar years. In order to see how this developed, it was necessary to go back to the earlier, Galician period.

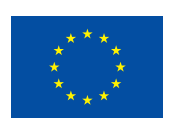

${ }^{1}$ This article was written for project no. 2015/19/P/HS3/04054 in programme Polonez 1 organised by National Science Centre which received funding from the European Union's Horizon 2020 research and innovation programme under Marie Skłodowska-Curie grant agreement no. 665778 .

2 Towarzystwo ku wsparciu biednych chłopców starozakonnych Hisaharu Bibne Amin, Szkoła dla analfabetów, Szkoła sług żeńskich, Stowarzyszenie ku wsparciu biednych uczniów Chawre Machzike Naare Bute Sefer, Stowarzyszenie ku zaopatrzeniu ubogich uczennic wyznania mojżeszowego w odzież i obuwie, grupa krakowska Towarzystwa Nadzieja ku wspieraniu ubogiej młodzieży żeńskiej szkół wyższych i średnich, in: Budżet wydatków i dochodów gm. M. Krakowa na okres od 1.07.1918 do 30.06.1919 r. i od 1.07 do 31.12.1919 1919: 102-162; Kozińska-Witt 2015b: 413-445. 


\section{Legislation in Galicia}

According to the commune law of $12^{\text {th }}$ August 1866 (ustawa gminna), as well as other commune laws binding in Galicia, a commune's responsibilities included care for the poor, overseeing the commune's welfare bodies and the prevention of begging. ${ }^{3}$

The commune laws stipulated that any income previously received by institutions for the poor, or, failing that, for the local poor fund under the jurisdiction of the parish priest, was henceforth to be paid to the communal poor fund (fundusz ubogich) administered by the head of the commune. ${ }^{4}$ This meant that, in keeping with the liberal tendencies of the Habsburg Monarchy policy, theoretical attempts were made to form a framework of secularised, bureaucratised charitable activity run by the local administration.

The government's efforts to establish 'institutes for poor' were not successful in Galicia, and none were established there. ${ }^{5}$ Secular charity, did not have a good reputation in the region - in 1861, it was derided by Krakow city councillor Walery Wielogłowski as "a goddess in crinoline and polished gloves". ${ }^{6}$ According to Wielogłowski, this "daughter of last century's philosophy wished in these acts of mercy to replace religious orders; not to feel more merciful, but with a direct share of alms to appropriate the gratitude of the poor". ${ }^{7}$ Yet this did not happen, since secular charity was in fact a source of resentment, aversion and detraction.

Wielogłowski continues:

The secular administration itself, though worthy, venerable, and scrupulously conscientious, evidently does not possess the spirit of initiative or the gift of artful mercy that knows how to increase funds to bring relief to human suffering.- - Let them therefore cede administration to the natural alms of Divine Providence, and thus free themselves from troubles and us from the increasing numbers of beggars of various calibres [...] We therefore see that we can make do without philanthropy and without new associations; the old ones merely need to be revived and to have the proper practice implemented. ${ }^{8}$

In 1900, Krakow municipal administration officer Rudolf Sikorski was also very critical of the tendency towards the secularisation of charity, arguing that the laws minimised the influence of the clergy and overburdened the government with welfare duties:

Commune law and affiliation law [...] transfer all the specific weight of paupers' welfare to the commune council and head. The above laws do not take into consideration the important factor of the commune's clergy in the welfare of the poor; for this reason too, owing to the excessive duties bearing on the commune, welfare is in Galicia not supported by more enlightened elements and any special legislation does not indicate any uniform organisation or development [...]. ${ }^{9}$

\footnotetext{
3 Sikorski 1900: 154-184, here p. 156.

4 Ibid.: 157-158.

5 Buzek 1913: 857. Józef Buzek (1873-1936), statistician, economist, Lwów University professor.

${ }^{6}$ Wielogłowski 1861: 9. Walery Wielogłowski (1805-1865), landowner, civic and political activist, publisher and regional assembly deputy.

7 Ibid.: 11.

8 Ibid:: 23-24.

9 Sikorski 1900: 158. Rudolf Sikorski was a doctor of law and municipal officer.
} 
The communes, of course, resisted any additional burden. The poor were treated as idlers and wastrels, and constituted an inconvenient but common element of the urban landscape. Krakow was no exception in this regard. As Wielogłowski wrote in 1861:

[...] Krakow is becoming a cluster and throng of all outcasts from throughout Poland, Germany, Bohemia and Silesia, and a haven for all society's rotten castaways. If this migration of beggars to us were to consist of cripples and old men, we would be glad to share bread with them and would deem it our religious duty to become the eye to the blind, the leg to the lame and the old man's crutch; but this is not so. The mob of Cracovian beggary consists of healthy, strong and often young vagrants, who despise work, loaf around their lives idly and are bankrupt in spirit, conscience and morals. ${ }^{10}$

The commune's task was rather to protect Krakow's citizens from bothersome poor people than to help wretches to return to productive society. Aid work was transferred to private or confessional institutions. Just before the outbreak of the Great War, Jerzy Michalski pointed to the contradiction between theory and practice:

Public care ought to be the main thing - the basis and foundation for private care, which should only supplement, support, add to it and finish it off. Therefore, private charities here can at times partially lend the commune support in its duty to provide for the impoverished, and moreover, they can even release it from this duty entirely. Only then, if the monies of these establishments, foundations and charity funds do not suffice, is the commune obliged to provide assistance. ${ }^{11}$

Even in 1917, Jan Stanisław Bystron placed care for the poor at the bottom of a list of the commune's responsibilities, after administration, attention to the city's appearance, sanitary duties and education. ${ }^{12}$ According to the economic historian Krzysztof Broński, almost to the end of the autonomous period, a major role in dealing with poverty was played by the aid provided by charitable foundations and private donors, rather than public authorities. ${ }^{13}$ Broński also believes that in this period no effective programmes were developed for counteracting poverty, for example through economic activity from interested parties.

Unfortunately, studies tell us little about the significance of the Elberfeld system, whose first implementation in Galicia came in 1900 in Krakow, ${ }^{14}$ and which individualised poverty, aiming through the decentralisation of aid work to help particular people to become economically active. The work of the new department for charity affairs established in the municipality (Department VI) was supposed to be based on the principles of this system. ${ }^{15}$ According to Sikorski and Buzek, however, it was the bureaucratic, not the social element that was dominant among those working with the poor, and from the outset they were each entrusted with too many people (30, rather than 3-4), thus rendering this venture a caricature of the prototype.

\footnotetext{
${ }^{10}$ Wielogłowski 1861: 3-4.

${ }^{11}$ Michalski 1904: 94-95. Jerzy Michalski (1870-1956), banker, economist, Jagiellonian University professor.

${ }_{12}$ Bystroń 1917: 13. Jan Stanisław Bystroń (1892-1964), ethnographer and sociologist, Jagiellonian University professor.

${ }_{13}$ Broński 2008: 9-27, here p. 26.

14 Buzek 1913: 873.

15 Sikorski 1907: 268-285, here p. 268.
} 


\section{The state law on the right to residence}

Communes were able to protect themselves from the costs of charity work with the aid of the '1863 State Law on the Right to Residence (prawo przynależności, prawo do swojszczyzny)', which set out the duty to provide aid solely on the home commune of the recipient of the charity. ${ }^{16}$

One's affiliation was acquired through one's father, or for a wife through her husband, by acquiring public office and by express acceptance to the commune association. ${ }^{17}$ It was very hard to change, and as a result, many residents of towns were unable to obtain affiliation rights. Whereas in 1880 some $55.4 \%$ of Krakow's inhabitants had been affiliated, ${ }^{18}$ by 1910 the figure had dropped to $34 \% .{ }^{19}$ This meant that a large number of the city's inhabitants were denied the right to charitable aid or to treatment in municipal hospitals.

What tended to happen in practice was that if a poor person fell into the hands of the authorities, they were dispatched to their commune of origin (szupasowanie), although they had no ties with this commune. In this way, the cities ridded themselves of beggars, the sick and unemployed, who of course took the first opportunity to return to the city, where they had much greater opportunities of getting a job or alms. The residence law was reformed only in 1896, when affiliation to a commune could be obtained by settlement over 10 years, as long as the resident did not constitute a burden to public charity at this time (Dz.u.p. $\mathrm{nr} 222){ }^{20}$

\section{Confession-based division of charity}

There was also another type of safeguard that Galician communes could employ to avoid the onerous obligation to provide aid. This came in the form of a division of charity on the basis of confession, which allowed communes to escape responsibility for impoverished local Jews. This was why from the very beginning funds for poor Jews were removed from the operation of the statute on the communal poor fund, and according to art. 92 of the commune statute from 12 August 1866 they were thence to be administered by the heads of the Jewish community, and not the political commune, as was theoretically the case for Christians.

As a result, care for the impoverished in Galicia from then on was, on the basis of articles 89-94 of the commune statute, divided between the Christian and Jewish populations. ${ }^{21}$ Whereas the welfare of poor Christians was regulated by the patent of Emperor Joseph from 23 November 1786 (Patent wegen Verpflegung der wahren Armen), that

\footnotetext{
${ }^{16}$ Bartoszewicz 1901: 24. Joachim Bartoszewicz (1867-1938), doctor, lawyer and national-democratic politician.

17 Buzek 1913: 858.

${ }^{18}$ Bystroń 1917: 4, 10.

19 Ibid: 10.

${ }^{20}$ Bartoszewicz 1901: 25.

${ }^{21}$ Sikorski 1900: 157.
} 
of poor Jews was regulated by the patent of 7 May 1789, the so-called Judenordnung. ${ }^{22}$ In art. 19, this patent imposed upon the heads of the Jewish community, and in the subsequent articles upon the whole Jewish community, the duty to support their coreligionists in poverty. It is important to note that, despite the adopting of constitutions and the equalisation of citizens' rights irrespective of religion (the December patent ${ }^{23}$ ), the division of charity was preserved until the end of the autonomous period.

As an eyewitness wrote, Galician "[...] public care for the poor, despite the new forms and legal relations, did not cease to be that which it had been previously, i.e. charity, intrinsically associated with religious concepts and [confessional] institutions". ${ }^{24}$

\section{City statutes}

Sections establishing the division of charity on the basis of confession were also included in the statutes of just two of the Galician cities among those in the Monarchy with the privilege of having their own statutes (Statutarstädte, miasta $z$ wtasnym statutem): Lwów and Krakow. When writing their statutes, which could not contain articles conflicting with the constitution - the December patent - city communes could take into account their unique development potential, which translated into fiscal strength. Both Galician commune law and the statutes of the cities of Lwów and Krakow contained sections and articles regulating the mutual relationship between territorial and confessional communities. $^{25}$

The foundation for the confession-based division of charity in Krakow was provided by the resolutions of the Temporary Commune Statute of 1866, and specifically Section 6 Title 17, "The influence of the commune authorities on matters concerning various religious confessions" 26 (this section survived in city statutes in an almost unchanged form until 1931). According to Article 119 of this section:

Each religious confession possesses and makes use of institutions, foundations and funds designated for its spiritual, scientific and charitable objectives, and makes its expenditure from its own resources. Each member of the commune of the city of Krakow contributes to the expenditure only of the religious confession to which he himself belongs $[\ldots] .{ }^{27}$

The notation repeated the resolutions of the 'Statute Administering Jews in the Free City of Krakow and Its District' (1817), ${ }^{28}$ and raised to the status of a binding law the earlier tradition of the confession-based division of charity, which stretched back to the estate structures.

22 Wasung 1908: 79. Michał Wasung/Wassung was a lawyer and city councillor.

${ }_{23}$ The December patent guaranteed the right to protection of personal freedom, the inviolability of property, freedom of confession (the right to public worship for churches recognised by the state, and public worship for others), the right to assembly, equality before the law and freedom of the press.

24 Bartoszewicz 1901: 80.

25 Kozińska-Witt 2015a: 58-68.

26 Tymczasowy Statut Gminny dla Miasta Krakowa 1866: 43-44; Sikorski 1900: 161-162.

27 Tymczasowy Statut... 1866: 43.

28 Jakimyszyn 2008: 118. 
Division by confession concerned not only charity, but also the way in which the city property was understood. Frequently it was viewed, as in Lwów, for example, as belonging solely to the Christians living in the city, ${ }^{29}$ invoking the privilege of Casimir the Great from 1356, when the king bestowed the city upon the Christian citizens. As Dr Michar Wasung, one of the Christian councillors put it:

The above property belonged solely to the commune of the city of Lwów, or to the citizens of the city of Lwów, that is the townspeople [mieszczanie], except that certain properties were expressly donated to Christian foundations and institutions, to Christian religious, scientific and charitable purposes. The citizens comprised only the Christian population, while the Jews, although permitted to live in the city, were regarded as aliens only staying in the city, or even as aliens with a community concluding trading agreements. In the statute of the city of Lwów, Stephen Báthory expressly indicated that Jews are not part of the city and are not townspeople, and do not even have anything in common with the townspeople. ${ }^{30}$

The fact that Jews held the functions of townspeople and had to pay taxes to the commune evidently escaped those using such arguments.

It is important to stress that these articles were an exception in the Monarchy, and no other town statutes referred to confessional communities and division of charity, although presumably such separation was a common practice in everyday life. But it was in Galicia that the majority of the "Austrian" Jews lived, and its cities were home to distinct Jewish quarters, within which confession-based charitable institutions operated. The articles in question therefore reflected a unique confessional situation, while also conserving divisions between confessions from a legal point of view.

These articles seem largely to have scuppered the initial aims of the reformers of the Monarchy, who hoped to secure a separation of state and church and establish bureaucratic social welfare.

In 1911 Dr Joachim Bartoszewicz, director of the Lwów statistical office and an expert on the subject, claimed: "[...] even today, despite numerous political and socio-legal changes, the church and the confession-based nature of welfare for poverty in this part of the Commonwealth known as Galicia has persisted". ${ }^{31}$

What Bartoszewicz went on to write is equally interesting:

The care for the impoverished carried out by the organs of the public administration (communes and counties (powiat)) cannot be called "Christian", for as an administrative activity it should be applied to all, regardless of confession - yet, nevertheless, in the vast majority of cases this welfare of the communes and counties bears a markedly confession-based, Christian character. The subsidies awarded here and there by the communes to Israelite charitable institutions and associations indicate only the non-denominational nature of commune welfare [underlining added]. Essentially, Jews are usually sent to the religious Israelite community or to establishments and institutions specially designated for them. ${ }^{32}$

As this statement shows, municipal subsidies for Jewish institutions could act as something of a fig leaf to mask the fact that charitable activity in Galicia continued to be

\footnotetext{
29 Hein-Kircher 2016: 29-42.

30 Wasung 1908: 90-93, here p. 90.

31 Bartoszewicz 1901: 80.

32 Ibid.
} 
almost exclusively determined by confession. Bartoszewicz does not make it clear from whom this fact was supposed to be hidden, but his words take on a particular meaning if we recall that the "defence of Galicia", which was regarded as provincial, backward and poor in the Monarchy, was an important task of the Galician elites. For example, writing about social welfare in the same text, the author also takes issue with the Austrian lawyer Ernst Mischler, a specialist in administrative affairs, who in his works wrote in rather unfavourable and very patronising terms about Galicia. ${ }^{33}$

Sikorski mentions three groups when writing of Krakow's paupers: "servants, jobbers and a considerable proportion of the Israelites in Kazimierz" ${ }^{34}$ This list shows that a large number of Krakow's Jews were treated as a problematic urban element. Despite the evident "wretched condition" of the streets where Jews lived and the destitution of their residents, a common belief was that they were more fortunate and better organised. Knowledge of the well-functioning charitable activity within the Jewish communes was widespread in this period:

Israelite charity developed separately from Christian charity. Just as it is carried out today, it was in the past too. The greatest activity was undertaken by the associations at the very numerous houses of prayer, who supported their members, meaning that distribution of assistance is rigorously controlled since the members of the society know each other well. This welfare, based almost solely on the principles of religion, is characterised by hugely advanced participation of the Israelite society in charitable associations $[\ldots] . .^{35}$

Statistics prepared in 1898 by the municipal statistics office at the behest of Krakow City Council revealed a total of 36 Jewish charitable institutions, including 18 houses of prayer and charity. ${ }^{36}$ Sikorski notes that, whereas Jewish charitable activity was concentrated on non-institutional welfare, its Christian counterpart was largely institutionbased. There were five times as many Christian establishments, but the Jewish associations were very numerous (10 times as many members). As a result, the income from members' contributions was three times higher than that in Christian institutions. Furthermore, Jewish associations made repayable loans to the impoverished, something not practised by Christian ones (although the denominationally neutral Prince Rudolf fund managed by municipality operated in a similar way ${ }^{37}$ ).

33 Also Michalski 1904: 127-129. Ernst Mischler (1851-1912), professor of statistics and financial law in Vienna and Prague, publisher of the monumental Österreichsches Staatswörterbuch.

34 Sikorski 1904: 23.

35 Sikorski 1900: 175.

36 Ibid.: 175, 181-184.

37 Kronprinz Rudolf-Stiftung, or Erzfürst Rudolf-Stiftung, a foundation established by Emperor Franz Joseph I in 1858 to mark the birth of his first-born son Rudolf, the heir to the throne. The Foundation's activities included making loans to impoverished craftsmen and supporting hospital and educational projects. 


\section{Jewish charitable societies and their subsidising}

An official report from 1867 written by Dr Stanisław Strzelecki, deputy mayor of the city of Krakow, referred to eleven Israelite charitable fraternities in Kazimierz, "established to engage in acts of mercy". These were:

Bikur Cholim, for visiting the sick and impoverished

Gemilath Chassidim, for providing loans

Malbusz Arunim, for distributing clothing to the poor

Gidul Jessonim, for raising orphans

Hachnasat Kalah, for clothing poor girls

Nosse Hamitah, for pre-funereal preparations

Kadisza Gemilath Chassidom szel Emeth, for conducting funerals

The Committee for orphanages for young children

The Society of civilised Israelites for providing aid to the impoverished

A similar society of women under the direction of P. Schreiberowa, the rabbi's wife

The Society of welfare for women in childbed. ${ }^{38}$

The deputy mayor also referred to an initiative that was only just getting underway: "[...] The Jews submitted for ratification a statute arranging charitable care under the name Hyzharu bibne Aniim for neglected boys, with the objective of enabling them to train in a mercantile, industrial or craftsmen's trade". ${ }^{39}$

This list mostly covers traditional associations. The presence of progressives can be observed in just two cases: the Society of Civilised Women and the emerging Society for the Support of Poor Jewish Boys. ${ }^{40}$

Whereas this first report contains no references to Jewish charitable associations receiving any allowances from the local government, the next report, from 1868, reads: "Finally the commune came to the aid of the committees of Christian refuges with a sum of 500 zloty reń[ski], the Jewish hospitals with 200 zloty reń[ski], and the Israelite orphanages with 100 zloty reń[ski]". ${ }^{41}$ In the late 1860 s, then, two institutions of the Jewish community - a hospital and an orphanage, i.e. the traditional institutions - were already receiving small allowances.

By 1914, there were a number of such subsidised institutions: 'Section X. Charity' refers to a whole host of Jewish private associations subsidised by the local government ${ }^{42}$ :

\footnotetext{
38 Strzelecki 1868: 20. Stanisław Strzelecki (1821-1878) was a lawyer.
}

Bikur Cholim do odwiedzania chorych ubogich, Gemilath Chassidim do udzielania pożyczek, Malbusz Arunim dla rozdawania odzieży między ubogich, Gidul Jessomim do wychowania sierót, Hachnasat Kalah do wyposażania panien ubogich, Nosse Hamitah do exportacyj przedpogrzebowych, Kadisza Gemilath Chassidim szel Emeth do sprawiania pogrzebów, Komitet ochronek dla małych dzieci, Towarzystwo Izraelitek cywilizowanych dla udzielania zapomóg ubogim, Podobne Towarzystwo kobiét pod kierunkiem P. Schreiberowéj rabinowéj, Towarzystwo opieki nad położnicami.

${ }^{39}$ Strzelecki 1868: 20.

${ }^{40}$ Maślak-Maciejewska 2015: 254-258. I am grateful to Dr Maślak-Maciejewska for making her unpublished $\mathrm{PhD}$ dissertation available to me.

${ }^{41}$ Strzelecki 1869: 21.

${ }^{42}$ Budżet wydatków i dochodów 1913: Section X, item 15.

1. Stowarzyszenie kobiet ku ochronie sierót izraelickich; 2. Towarzystwo ku wspierania biednych chłopców starozakonnych pod godłem Hisaharu Bibne Amim; 3. Stowarzyszenie dla przytułku biednych starców 
1. The women's association for the protection of Israelite orphans

2. The society for supporting poor Jewish boys under the banner of Hisaharu Bibne Amim $(\text { from 1868) })^{43}$

3. The association for the refuge of the impoverished elderly under the banner of Asyfas Skenim $^{44}$

4. The Association for the Support of Poor Peasant Pupils of the Mosaic Faith under the banner of Chewre Machzide Naare (from 1877) ${ }^{45}$

5. The Association for the Provision of Clothing and Footwear to Impoverished Jewish Schoolgirls (c. 1889) (6) $^{46}$

6. The association for the support of Israelite craftsmen under the banner of Szomer Umonim (from 1874)

7. The association for the care of the poor and sick under the banner of Bikur Cholim

8. The association for provision of clothing to the impoverished under the banner of Malbusz Erunim/Malbisz Arimim

9. The society of holiday camps for Israelite children of folk schools (from 1890) ${ }^{47}$

10. The "School cooking for free" association for children without differentiation of confession or sex attending public schools (from 1887) ${ }^{48}$

11. The committee for the cheap Jewish soup kitchen

12. The association for distribution of alms and coal under the banner of Kupa-Zeduku (from 1874)

13. The association for bringing aid to poor and sick Jewish convalescents of Krakow hospitals

14. For the hospital of the Israelite confessional community

15. The Krakow group of the Hope Society for supporting impoverished and sick Galician youth studying at middle and higher schools

16. The Union of Jewish Women

Apart from charitable institutions, educational ones were also subsidised, such as a school for the illiterate (from 1897), ${ }^{49}$ or for Jewish servants, as well as, in the last years before the war, Talmud Torah.

The number of progressive institutions being subsidised increased considerably over time, not least because more and more of them were established. Most of them dealt with the broad goal of increasing productivity among Jews, which was the progressives'

pod godłem Asyfas Skenim; 4. Stowarzyszenie ku wsparcia biednych uczniów ludowych wyznania mojżeszowego pod godłem Chewre Machzide Naare; 5. Stowarzyszenie ku zaopatrywaniu ubogich uczennic wyznania mojżeszowego w odzież i obuwie; 6. Stowarzyszenie ku wsparciu izraelickich rękodzielników pod godłem Szomer Umonim; 7. Stowarzyszenie ku pielęgnowaniu biednych chorych pod godłem Bikur Cholim; 8. Stowarzyszenie ku zaopatrzeniu ubogich w odzież pod godłem Malbusz Erunim/ Malbisz Arimim; 9. Towarzystwo kolonii wakacyjnych dla izraelickiej dziatwy szkół ludowych; 10. Stowarzyszenie pod nazwą „Kuchnia szkolna bezpłatna” dla dziatwy bez różnicy wyznania i płci uczęszczającej do szkół publicznych; 11. Komitetowi taniej kuchni izraelickiej; 12. Stowarzyszeniu ku rozdzieleniu jałmużny i węgla pod godłem Kupa-Zeduku; 13. Stowarzyszenie ku niesianie pomocy biednym chorym ozdrowieńcom wyznania mojżeszowego szpitali krakowskich; 14. Wyznaniowa gmina izraelicka na szpital; 15. Grupa krakowska Towarzystwa Nadzieja ku wspieraniu ubogiej chorej uczącej się młodzieży galicyjskiej szkół średnich i wyższych; 16. Związek niewiast żydowskich.

${ }^{43}$ Maślak-Maciejewska 2015: 254-258.

${ }^{44}$ Ibid.: 272-275.

${ }^{45}$ Ibid.: 258-261.

${ }^{46}$ Ibid: 263.

${ }^{47}$ Possibly identical to the Society for Curative Summer Camps of Israelite School Children, ibid: 263-266.

${ }^{48}$ Ibid.: 261-263.

49 Ibid: 270. 
main objective, whether by offering material support to schoolchildren or by enabling them to acquire a professional education. Here we ought to stress one unique initiative: that of the cheap soup kitchen, intended to cater for children irrespective of confession. ${ }^{50}$ Such neutrally confessional gestures were also initiated on occasion by the Christian side (e.g. a homeless shelter in Kazimierz, serving of Rumford's Soup every winter), but the cheap kitchen founded by the progressives was a permanent venture organised by an association of ladies subsidised by the local government.

To receive subsidies, associations had to satisfy the certain requirements and conform to procedures: e.g. presenting modern statutes, submitting a request for subsidies and accounting for monies received. Michalski notes that the only private charitable associations that could receive state subsidies were those which remained in contact with the poor authority, provided them with the explanations they required, and acted in accordance with them. ${ }^{51}$ The procedure on the municipal level was probably similar.

It is likely that traditional associations were reluctant to meet these demands. Mayor Feliks Szlachtowski's report from 1886 reads:

[...] Israelite charitable associations [...] delay sending responses [regarding the support fund and people given support], but there is a hope that, with the help of the Israelite assembly, it will be possible to persuade these associations to rectify the summons in order to present a complete picture of public charity in our city. ${ }^{52}$

Bartoszewicz wrote that: "The Jewish associations in particular have not been quick to provide their funds and income". ${ }^{53}$

The disproportionately high number of progressive associations receiving subsidies could be explained by procedural requirements. Their dominance on the list of subsidised organisations may have been caused by the aforementioned non-institutional nature of traditional Jewish charity. A major factor in the distribution of subsidies was also certainly the strong representation of progressives in the local municipal government.

The institutions that were subsidised in 1914 were also subsidised in the first years of independence. I suspect that this might indicate a certain administrative automatism and adoption of pre-war practices.

The list of subsidised institutions reflects the influence of the new residence law of 5 December 1896 (Dz.u.kr. nr 222), which came into effect in Galicia in 1901, since in this period the number of subsidised institutions increased, along with the total subsidy amounts. The law made it possible to gain affiliation after 10 years of residence, and thus increased the number of people eligible for aid. ${ }^{54}$ Józef Buzek wrote that within two years of the implementation of the new law in 1901-1902, 1,983 people had gained the right of residence (prawo przynależności) in Krakow. ${ }^{55}$ In 1910 alone, meanwhile, the number of residents grew by $6 \%$ : from $34 \%$ to $40 \%{ }^{56}$

\footnotetext{
${ }^{50}$ Thanks to Dr Alicja Maślak-Maciejewska for bringing my attention to this aspect of the progressives'

51 Michalski 1904: 97.

52 Sprawozdanie prezydenta miasta 1887: 27.

${ }_{53}$ Bartoszewicz 1901: 80.

${ }^{54}$ Sikorski 1900: 163.

55 Buzek 1913: 868.

${ }^{56}$ Bystroń 1917: 10.
} activity. 
The increase in Krakow's city boundaries did not have a marked impact, since the rural neighbouring communes were mostly populated by Christians, with only a few Jews. An exception was industrialised Podgórze, but this was only incorporated during the First World War, in 1915.

\section{The sources of subsidies}

We should start by stressing that very small sums were made available for charitable causes: in 1883 they amounted to $3.54 \%$ of Krakow's municipal budget, while in 1887 they came to $3.41 \% .{ }^{57}$ Lwów gave only slightly more, with $5.03 \%$ and $4.44 \%$ in 1883 and 1887 respectively. (Prague was more generous, with figures coming to $6.83 \%$ and $9.13 \%$ respectively, as was Vienna: $15.25 \%$ and $16.98 \%$ respectively.) As mentioned at the outset, such support was not considered a main task of the political administration.

Jewish charity was financed firstly from special bequests (legaty) administered by the city. In 1870, therefore, the city managed the following: the Ignacy Paprocki Fund for supporting orphans of the Israelite confession, the Lewek Weicenblum and Chajm Kretzer fund for the perpetual illumination of the Israelite Synagogue, the Teresa Abelles dual fund for supporting various Israelite fraternities and for the support of orphaned boys of the Israelite confession, the Maurycy Inländer fund for the Israelite hospital, and the Zygmunt Löbenstein fund for supporting two convalescents of the Israelite confession. ${ }^{58}$ It is also worth mentioning the Salomon Wechsler fund, which came about from an 1873 bequest to be distributed half-and-half to impoverished Christians and Jews. ${ }^{59}$

The second source of subsidies was the paupers' fund, which constituted a legally distinct subject and which the commune could only use on provisions for the impoverished. It received:
Discretionary donations
Donations to the church collecting box
Bequests and foundations for the poor
The third part of the inheritance from priests dying intestate
One percent of the purchase at discretionary auctions
Political and court fines and pecuniary penalties balls and for public productions
Police fees
From $1900,2.5 \%$ of the totalisator bets at horse races
Bicycle taxes. ${ }^{60}$

Taxes for granting permits for keeping inns open after the curfew, for music with dancing, for

Only two types of fees - donations to church collection boxes and inheritances from priests - could not be earmarked for charity to Jews. The totals from the final two feesthe totalisator and bicycle taxes - were probably divided according to a certain set proportion: this was in any case true of Lwów. Wasung notes that this city's urban commune donated one third of the income from entrance tickets to shows and spectacles, as well as

\footnotetext{
57 Sroka 2012: 170.

58 Budżet dochodów i wydatków... 1870: 24-26.

59 Zamknięcie rachunków... 1880.

${ }^{60}$ Sikorski 1900: 157; Bartoszewicz 1901: 32-33; Michalski 1904: 82-83.
} 
police taxes on dances, shows and public spectacles (in 1906 some 11,500 crowns) to the Jewish poor fund ${ }^{61}$ and two thirds remained at the disposal of section I of the municipal council for extraordinary subsidies for the Institute of Poor Christians or other charitable institutions. $^{62}$

The main financial sources of the subsidies were fines levelled at Jews, police fees and permit charges. This was authorised by art. 122 of the Krakow statute, which stated, "income for satisfying the needs of the city's residents shall be distributed for the use of each confession, in relation to the contribution of its followers". ${ }^{63}$ As a result, the Jews themselves financed subsidies to Jewish institutions.

The municipality's sole role here was to levy, distribute and pay out according to the philosophy: from Jews for Jews. I would argue, however, that the function of the intermediary was a small step towards the secularisation or bureaucratisation of the charity process. Mediation by the municipality meant that discussions took place in the local government forum on how best to divide the sums collected and what institutions should be subsidised. Therefore, the individuals who influenced decisions did not need to be well known in the Jewish community and could back subsidies of initiatives which were not of high priority for those dominant in the confessional community. Permitting mediation of the municipal authorities, however, was not a particularly revolutionary concession, since charity continued to be based on confessional affiliation.

The beginning of the city's mediation in the distribution of subsidies in Krakow probably came in the 1860 s, when the progressives organised the Municipal Department for Israelite Affairs in the city's local government, with the intention of replacing the Orthodox commune board. ${ }^{64}$ In this case, the Jewish institutions would be directly subordinate to the city administration. The Krakow progressives wished to pursue a typical maskilic programme, placing enlightened secular authority ahead of the 'obscurantist' Orthodox version. Though they were unsuccessful in this, the idea of administrative mediation between the Jews and confessional institutions was not entirely new in Krakow.

\section{Krakow versus Lwów}

Whereas in Krakow one could speak of a certain rudimentary secularisation of the process of subsidy distribution, since it was decided upon by non-confession-based municipal circles, in Lwów the process remained entirely bound by confession. The municipality did not mediate at all in Galicia's capital. ${ }^{65}$ Monies from fines went directly to the Jewish Poor Fund administered by the Jewish community, where they were divided appropriately. ${ }^{66}$ The distribution process was thus able to bypass the municipal local government.

\footnotetext{
${ }^{61}$ Wasung 1908: 86.

62 Bartoszewicz 1901: 87.

63 Tymczasowy statut... 1866: 44.

64 Ibid.; Kozińska-Witt 1999: 120-121, 123-128.

65 Bartoszewicz 1901: 44.

66 Wasung mentions the Israelite Poor Account, whose establishment in 1874 followed negotiations with the municipality of the city of Lwów; Wasung 1908: 85.
} 
A similarly direct transmission of fines to the Jewish commune also occurred in one case in Krakow, because in the early Galician period some of the penalties levied on Jews were paid out to the Jewish hospital. The main source of subsidies to the hospital was fines for failure to register the birth of a child to the rabbinate. There were a great number of such penalties, the vast majority of which could not be executed owing to the poverty of the parents. The surviving municipal files indicate close collaboration between the municipality and the rabbinate when this omission was pursued.

Transferring penalties to the hospital was probably an old custom dating from the times of the Republic of Krakow, or perhaps even earlier. It is important to note that the hospital was the only institutional property of the Jewish community. Other charitable institutions were the property of private associations.

A possible explanation for the differences in the way money was transferred to Jewish institutions would be the existence of two independent funds: those of the hospital and the administration. Fines for failure to register children in the rabbinate were thus, for a certain period, apportioned directly to the hospital, while administrative penalties would be paid to the administrative fund, with which other Jewish institutions were replenished, as negotiated in the local government forum.

The subsidy for the Jewish hospital was only recorded in the Krakow city budgets in 1906, although Deputy Mayor Strzelecki mentioned it as early as 1868 . Why did the subsidising of the hospital only begin to be itemised in the budgets in 1906? I have yet to find an explanation for this. It is important to stress, however, that there is an interesting temporal correlation between the subsidy for the hospital in Krakow and subsidising of Jewish institutions in Lwów.

Dr Maks Schaff, an eminent Lwów social activist, stated that Lwów local government began to subsidise Jewish institutions regularly during Dr Emil Byk's term as president of the board of the Jewish commune, i.e. in 1902-1906. ${ }^{67}$ Bartosiewicz too reported in 1908 "the commune of the city of Lwów subsidises Israelite charitable institutions and establishments". ${ }^{68}$ In 1908, Wasung referred to subsidies of Lwów city council paid out from commune funds or the general income for the local poor fund, distributed according to the decision of the local city government. ${ }^{69}$

The Jewish inhabitants of both cities who paid financial penalties to the city authorities themselves financed the municipal subsidies then transferred to the Jewish commune. It is likely that these fines initially fully covered the subsidies. Later, however, the penalties and charges would have had to increase radically, which would have been discriminatory and absurd. It therefore proved necessary to find alternative sources of funding for subsidies. Art. 35 of the commune law made it clear that "should the establishments and funds designated for helping the impoverished prove insufficient, the commune council shall seek to procure the necessary funds and may determine the way in which they are used". ${ }^{70}$ From the very beginning, the commune's obligation to provide aid was subsidiary, i.e. the commune was to offer it only when:

\footnotetext{
67 Schaff 1928: 2. Maks Schaff was a lawyer and social activist.

${ }^{68}$ Bartoszewicz 1901: 86.

69 Wasung 1908: 85. Financial penalties from Israelites 18,000 crowns.

70 Sikorski 1900: 156-157.
} 
the aid of existing poor and charitable establishments and foundations, and likewise third parties, obliged to supply a needy person, be it according to common civil law (arts. 91, 117, $139,143,154,166,183$ ), or according to other laws (mining, industrial law, law on workers' safety, regulations on servant staff, on aid funds) proves to be insufficient (arts. 22 and 23 al.1 leg.cit.). ${ }^{71}$

In such a case, the commune council was to procure the necessary funds (i.e., in the commune budget), and it should ratify covering these costs from the commune's general income. ${ }^{72}$ Any shortfall could be covered from the general funds by passing a commune council resolution to distribute it to individual members of the commune.

The reform of the residency law meant that the previously meagre funds earmarked for charity became insufficient. This is demonstrated by the reports on the work of the Lwów local government from 1908, which refer to the considerable sums - specifically one-sixth of the amount designated for charitable purposes for the disposal of the Section of the Commune Council (8633 crowns) - which the city commune had paid to the Jewish poor fund and individual Jewish charitable institutions. ${ }^{73}$ In total, the Lwów Jewish poor fund received around 56,000 crowns from the city commune. Wasung even claimed that Lwów city commune loyally subsidised the Israelite confessional community, even though "by the patent of Joseph II's Judenordnung its assets were not mixed with the political commune, but left to it, with an express provision to meet the needs of the impoverished Jewish population". ${ }^{74}$ The situation was presumably similar in Krakow, with the city paying Jewish charitable institutions certain amounts from the general budget.

Michalski's account of the 1897 debate in the regional parliament [Sejm Krajowy] on the necessity of issuing a separate Galician act on poverty cites opinions that the communes' financial resources were largely insufficient for adequately fulfilling their duties to provide for and give aid to the poor: "the applicant [Lwów mayor Godzimir Małachowski] requested consideration of the need for cooperation in this measure of commune and regional funds". ${ }^{75}$ Yet no appropriate act was issued before the end of the Galician period, while collaboration encompassed exclusively the regional government funds that the Regional Department (Wydziat Krajowy) transferred to communes for medical treatment costs for the impoverished.

To date we do not know what role the introduction of the Elberfeld system played in the process of the bureaucratisation of charity. It does seem likely, however, that the implementation of this system was also confession-based. In Kazimierz, its structures were formed in the early $20^{\text {th }}$ century. ${ }^{76}$ In 1901 , there were 11 welfare workers in operation there, each with an average of 41.73 impoverished individuals in their care. In 1902 the Kazimierz district was divided into two sections - the eastern Kazimierz part (13 welfare workers: 27.08 clients each) and western Skałeczna part (eight welfare workers: 22.23 clients); the boundaries were Mostowa Street and Boże Ciało Street. This separation "conserved" the traditional division between the former Jewish Town and Christian Kazimierz.

\footnotetext{
71 Michalski 1904: 79.

72 Buzek 1913: 858.

73 Wasung 1908: 86.

74 Ibid.: 93.

75 Michalski 1904: 131.

76 Sikorski 1907: 264.
} 


\section{Conclusion}

The way in which subsidies were distributed supports Antony Polonsky's contention regarding Krakow's lasting socio-confessional division: "The city was also largely conservative and pre-industrial, and the fact that two societies-Polish and Jewish-were largely separate, may, paradoxically, have eased their coexistence". ${ }^{77}$

By accepting Polonsky's argument in the analysis of charitable activity in the city, we can make use of the model of the Austrian church historian Rupert Klieber, which refers to various confessional "rooted" aid systems operating in cities, which were home to followers of various religions. ${ }^{78}$ These systems worked independently, taking care above all of their "own lambs". In Galicia, this tradition was stabilised legally by the regional law that was in place.

Of course, this state of affairs stirred emotions. The Jews in the cities were the "financing estate", as only through their taxes were the communes able to function. They held the leases of most tolls and owned or subleased the majority of permits, the fees from which made large contributions to the city budget.

The argument that because of these financial contributions Jewish institutions should be better financed was expressed mostly in the press. An article from 1907 in Wschód, for example, stated that Jews had the right to demand:

that the commune, in fulfilling the duties that the act places upon it towards its members, render them uniformly to all its members, in order that within it exceptional acts should not be created to our detriment, and for the money that we too very seriously contribute not to be used against or in spite of us. ${ }^{79}$

The entitlement argument raised in arena of municipal councils seems to be mainly a product of democratisation, when the representatives of Jewish mass parties representing an entirely different electorate entered local government. In the interwar period, discussions on this topic became among the most important.

Translated from Polish by Ben Koschalka

\section{BIBLIOGRAPHY}

Bartoszewicz, J. (1901), Opieka nad ubogimi w Galicyi, in: Wiadomości statystyczne o stosunkach krajowych, Vol. XVIII, Lwów.

Broński, K. (2008), Kwestia opieki publicznej nad ubogimi w Galicji w dobie autonomicznej (wybrane problemy), Zeszyty Naukowe / Uniwersytet Ekonomiczny w Krakowie 779: 9-27.

Budżet dochodów i wydatków miasta Krakowa za rok 1870 (1870), Kraków.

Budżet wydatków i dochodów gm. M. Krakowa na okres od 1.07.1918 do 30.06.1919 r. i od 1.07 do 31.12.1919 (1919), Kraków.

\footnotetext{
77 Polonsky 2011: 114.

78 Klieber 2013: 209-233.

79 Wasung 1908: 87-88, here p. 88.
} 
Budżet wydatków i dochodów gminy miasta Krakowa od 1. Stycznia 1914 do 30. czerwca 1915 (1913), Kraków.

Buzek, J. (1913), Administracya gospodarstwa społecznego, Lwów.

Bystroń, J.S. (1917), Pięćdziesięciolecie samorządu Krakowa 1866-1916, Kraków.

Hein-Kircher, H. (2016), Polityczna integracja w mieście wieloetnicznym: podstawy prawne i ich wpływ na sytuację Żydów we Lwowie po roku 1870, Res Gestae 2: 29-42.

Jakimyszyn, A. (2008), Żydzi krakowscy w dobie Rzeczypospolitej Krakowskiej. Status prawny. Przeobrażenia gminy. System edukacyjny, Kraków-Budapest.

Klieber, R. (2013), Von der Mildtätigkeit zum sozialpolitischen Engagement. Konfessionelle Antworten auf die Soziale Frage der Habsburgermonarchie 1848-1918, in: M. Maurer, B. Schneider (eds.), Konfessionen in den west- und mitteleuropäischen Sozialsystemen im langen 19. Jahrhundert. Ein „edler Wettkampf der Barmherzigkeit"?, Berlin: 209-233.

Kozińska-Witt, H. (1999), Die Krakauer Jüdische Reformgemeinde 1864-1874, Frankfurt/M. et al.

Kozińska-Witt, H. (2015a), Krakauer Munizipalität und jüdische Konfessionsgemeinde. Provisorisches Gemeindestatut für die königliche Hauptstadt Krakau (1866) und seine Wirkung, Historica-Review in History and Related Sciences 6.1: 58-68.

Kozińska-Witt, H. (2015b), Samorządowa polityka przyznawania subwencji wobec potrzeb żydowskich mieszkańców Krakowa (1918-1939), Kwartalnik Historii Żydów 255: 413-445.

Maślak-Maciejewska, A. (2015), Z dziejów judaizmu w XIX-wiecznym Krakowie-tożsamość, poglady religijne $i$ instytucje postepowe, Kraków. Unpublished doctoral thesis.

Michalski, J. (1904), Prawo ubogich, Kraków.

Polonsky, A. (2011), The Jews in Poland and Russia, 1914 to 2008, Vol. 3, Oxford-Portland.

Schaff, M. (1928), Żydowska Gmina Wyznaniowa a opieka, Przegląd Spoleczny 9: 1-5.

Sikorski, R. (1900), Opieka nad ubogimi w Krakowie w roku 1898, Statystyka miasta Krakowa, Zeszyt VII, Kraków: 154-184.

Sikorski, R. (1904), Kraków w roku 1900 oraz jego podat administracyjny w ciagu XIX stulecia, Kraków.

Sikorski, R. (1907), Opieka gminna nad ubogimi w Krakowie w r. 1901 i 1902, Statystyka miasta Krakowa, Zeszyt IX, cz. II, Kraków: 268-285.

Sprawozdanie prezydenta miasta z czynności Rady miejskiej i Magistratu krakowskiego za rok 1886 odczytane na posiedzeniu Rady miejskiej w dniu 3. Marca 1887 (1887), Kraków.

Sroka, Ł.T. (2012), Rada Miejska we Lwowie w okresie autonomii galicyjskiej 1870-1914: studium o elicie władzy, Kraków.

Strzelecki, S. (1868), Gmina Krakowska. Sprawozdanie urzędowe z roku 1867, Kraków.

Strzelecki, S. (1869), Gmina Krakowska, Sprawozdanie urzędowe za rok 1868, Kraków.

Tymczasowy Statut Gminny dla Miasta Krakowa (1866), Kraków.

Wasung, M. (1908), Opieka nad ubogimi. I Rys opieki nad ubogimi otwartej (pozaprzytutkowej), Lwów.

Wielogłowski, W. (1861), O żebractwie w Krakowie, Kraków.

Zamknięcie rachunków różnych funduszów pod zarządem Gminny zostających za rok administracyjny 1880 ([b.d.]), Kraków. 